

International Journal of Emerging Technology and Advanced Engineering

Website: www.ijetae.com (E-ISSN 2250-2459, Scopus Indexed, ISO 9001:2008 Certified Journal, Volume 11, Issue 12, December 2021)

\title{
Design of a Mobile Application to Help Overweight People in Peru with the use of Chatbots
}

\author{
Rosa Perez-Siguas ${ }^{1}$, Hernan Matta-Solis ${ }^{2}$, Eduardo Matta-Solis ${ }^{3}$ \\ ${ }^{1,2,3}$ Universidad María Auxiliadora \& Av. Canto Bello 431, San Juan de Lurigancho
}

\begin{abstract}
In this research we have seen that in Peru there is a large number of overweight people in a range that exceeds at least $30 \%$ depending on the age range, between 20 and 29 years there is $\mathbf{3 0 . 4 0 \%}$ overweight, between 30 and 39 years there is $43.70 \%$ overweight, between 40 and 49 years there is $46.80 \%$ overweight, Between 50 and 59 years old there is a $43.30 \%$ of overweight and from 60 years old onwards there is a $38.50 \%$ of overweight, that is why we have proposed a prototype of a mobile application, whose main function is to help through the interaction of chatbots technology to have better control over their feeding and physical The development of the application will be done with an agile methodology, using the Scrum framework and the Balsamiq Mockup tool that will help us to design the prototypes of each module of the application. In the case of the study the requirements were made, and the planning of each sprint to carry out the application in a determined time. As a result, the design of the application is shown with modules to register users, register their weight and height to calculate their Body Mass Index (BMI), a section to interact in a chat to make any consultation, and finally a list of recipes with healthy dishes. This application will be very useful for all people who want to improve their health since it is not only for aesthetics, but also to prevent fatal diseases at an early age.
\end{abstract}

Keywords - Chatbots, Design, Mobile Application, Overweight.

\section{INTRODUCTION}

In large countries such as the United States, it is a trend that about $30 \%$ of the population per state is overweight or obese, this leads to more dangerous diseases such as type 2 diabetes, high blood pressure, and many cancers such as papillary thyroid [1]. Another of the countries with the largest overweight population is China, although in this country there is a difference, most of the people who are overweight are among children and adolescents, however, now in both countries, there are campaigns in the classical media such as television and radio stations, also in social networks to raise awareness about their health [2].
Peru is the third country with more cases of overweight in Latin America according to studies conducted in the regions Junín and Huancayo can be seen that people mostly do not perform physical activity and eat in a disorderly manner and unhealthy food such as junk food [3].

Many methodologies are adapted to work with the construction of our mobile application, and we chose an agile methodology so we can work with the Scrum framework. The technological changes in this digital revolution have encouraged many companies to be in constant innovation so that they can respond to the needs of the current market these companies adopted the agile methodologies since it allows them to adapt their way of working to the conditions that are necessary for the project [4]. Agile methodologies are mostly suitable for short projects, such as mobile application development [5]. This agile approach allows having constant changes since they have to satisfy a series of requirements and special conditions for the user [6]. Finally, the Balsamiq Mockups tool was used since it is one of the best tools to make constructions of the design modeling of web and mobile applications. It is easy to use and contains a great variety of tools to detail what is necessary for the modeling of the prototype.

This article uses the design of a mobile application for people with overweight problems in Peru with the use of Chatbots, so we can analyze the status of their body mass index of each person, taking into account the percentage of obesity that exists in Peru and decrease with healthy food [7]. To have healthy people using this mobile application with personal data and interacting directly with the use of Chatbots [8]. It will also include the food or menu to choose from and update people's data.

The objective is to design a mobile application to improve the quality of life of people with overweight problems in Peru using Chatbots. 


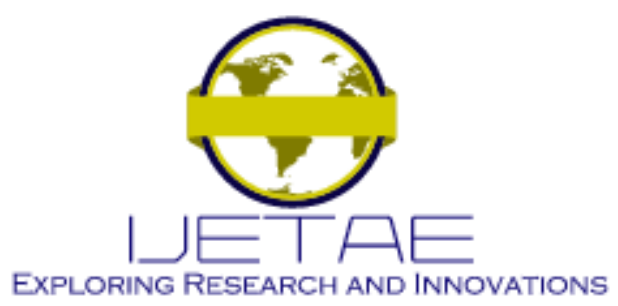

International Journal of Emerging Technology and Advanced Engineering

Website: www.ijetae.com (E-ISSN 2250-2459, Scopus Indexed, ISO 9001:2008 Certified Journal, Volume 11, Issue 12, December 2021)

The points to be discussed will be, in section II methodology, where the use of the scrum framework will be seen and the tools to be used for the development of the mobile application will be presented, then in section III the case study will be made according to the methodology used, then in section IV the results and discussions will be presented, finally, in section $\mathrm{V}$ the conclusions will be given.

\section{Methodology}

In this section, we will specify what steps will be, followed for the development of the mobile application, for which we will use the agile Scrum methodology since its working method, and continuous reviews will help us to have a higher quality of mobile application (software). It will also be detailed about the tools that are more adaptable for the development of the mobile application.

\section{A. Agile Scrum Methodology}

The main objective of this framework is to plan and control projects with constant changes [9].

Backlog Planning: In this phase, the requirements of the system are defined, classified by priorities, and the planning of Sprint 0 is also carried out, in which the objectives and the work to be done for this iteration are decided. Finally, in this meeting, you will get a Sprint Backlog, which is a list of tasks [10].

Sprint Tracking: In this phase, daily meetings are called, where the following questions are asked: What work has been done since the previous meeting? What work will be done until a new meeting? What problems have arisen that need to be solved to continue? [10].

Sprint Review: performed, final results or a demo must be submitted [10], Fig. 1 tells us how the sprint revision is given in the scrum process.

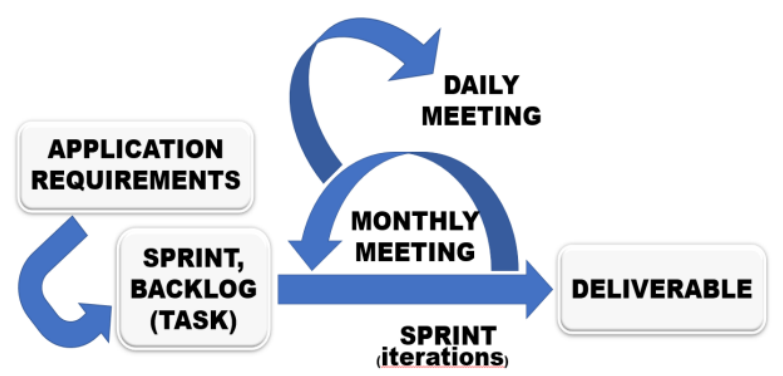

Fig. 1. Branches of artificial intelligence

\section{B. Development Tools}

To make the development, we will first use the Balsamiq tool to have an adequate design for the application because it will help us to make the prototyping easily and simply, taking into account the activities to carry out, in the same way, to have a guide in the elaboration of our project, when culminating with the prototyping in Balsamiq another tool will be implemented to have a clarity of as it would be the project with the tool FLINTO to obtain a better design of interface in sample mobile application, having a final stage of the prototyping in the project. Then, once the prototype design is finished, the Kotlin programming language will be used, which is compiled on a virtual java machine, having the utility in the native development in the Android [11], also it is a language that helps the user to reduce the repetition of code and with this, it can save resources and time, also the development environment Android Studio will be used since it allows to make programming in a work environment Framework of Java [12], besides, this environment is compatible with Firebase which, is a platform for the development of mobile applications that provides the database in real-time and identification of users [13], which guarantees that the application will have a high performance in real-time; finally the Chatbots will be implemented, which is software that through the use of artificial intelligence, allows maintaining structured conversations between a Bot and a human interlocutor, all this through already structured answers des the database in real-time and identification of users [14], this will allow the application of tips by default to the user either to give them a diet according to their body mass index or basic exercises they can do to burn calories.

\section{CASE STUDY}

In this section, we will develop the methodology with the steps already explained in more detail to have a vision of how the application will be done.

\section{A. Planning}

Here we will analyze the requirements and then make the user stories and make an estimate with planning poker to manage the backlog.

Requeriments: We propose the requirements that are essential for the application to function correctly. 


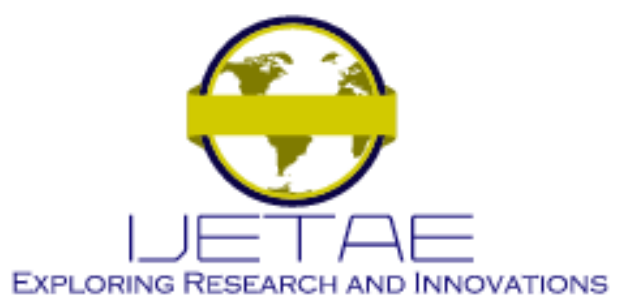

International Journal of Emerging Technology and Advanced Engineering

Website: www.ijetae.com (E-ISSN 2250-2459, Scopus Indexed, ISO 9001:2008 Certified Journal, Volume 11, Issue 12, December 2021)

- The application must allow a user to register with their data.

- The application must allow us to enter the platform through a registered login and password.

- The application must have a menu that includes the following points: Body Mass Index, user profile, my diet, and online consultation.

- The application within the body mass index option must calculate with the help of the user's height and weight.

- The application within the options user profile must allow changes such as cell phone number, email, and password.

- The application within the option my diet must have healthy food and some easy to prepare recipes.

- The application within the option online consultation must have chatbots already automated that answers frequent questions like basic exercises, some foods, information of a specific nutritionist.

User Stories: The user stories are raised according to the requirements; these are detailed requirements that the application must solve [15].
- As a user, I want to be able to register to be able to enter the application.

- As a user, I want to be able to access the application with a login and password.

- As a user, I want to register my weight and height to calculate my body mass index.

- As a user, I want to know if my body mass index is good or bad to know an approximate of what exercise routine is convenient for me.

- As a user, I want to access the option of my profile to modify data such as email, cell phone, password.

- As a user, I want to be able to see a list of healthy foods to correct my diet.

- As a user, I want to be able to see a list of recipes of healthy dishes easy to prepare to improve my diet.

- As a user, I want to be able to access an online consultation to ask frequently asked questions so that I can have virtual support.

Backlog Managment: In this part, the user stories will be managed according to the priority for the application; in table 1 it can be seen in more detail.

TABLE I

BACKLOG MANAGMENT








International Journal of Emerging Technology and Advanced Engineering

Website: www.ijetae.com (E-ISSN 2250-2459, Scopus Indexed, ISO 9001:2008 Certified Journal, Volume 11, Issue 12, December 2021)

Estimate planning poker: This estimate is used to indicate the measure of complexity for the development of the user stories and the value is only understood by the development team [16]. In table 2, it can be seen in more detail.

TABLE II

ESTIMATE PLANNING POKER

\begin{tabular}{|c|c|c|}
\hline $\mathbf{N}^{\circ}$ Ítem & Estimate planning poker & $\mathbf{N}^{\circ}$ Ítem days \\
\hline 1 & 3 & 2 days \\
\hline 2 & 2 & 5 days \\
\hline 3 & 5 & 42 days \\
\hline 4 & 12 & 3 days days \\
\hline 5 & 4 & 4 days \\
\hline 6 & 3 & 2 days \\
\hline 7 & 4 & 35 days \\
\hline Total & 2 & \\
\hline
\end{tabular}

\section{B. Sprint Tracking}

Here we will plan the sprints according to the backlog management explained in table 1.

For the development of sprint 1, user stories with high priority were taken, the people responsible for each story were selected, among other aspects that will be seen in more detail in table 3 .

\section{TABLE III}

SPRINT 1 REGISTRATION AND USER LOGIN

\begin{tabular}{|l|l|}
\hline \multicolumn{2}{|l|}{ SPRINT 1 } \\
\hline User History & $\begin{array}{l}\text { As a user, I want to be able to } \\
\text { register to be able to enter the } \\
\text { application. }\end{array}$ \\
\hline Manager: & Huayllani \\
\hline $\mathrm{N}^{\circ}$ Ítem: & 1 \\
\hline Estimated Time: & 3 days \\
\hline User: & User \\
\hline $\begin{array}{l}\text { Criteria of } \\
\text { Acceptance: }\end{array}$ & $\begin{array}{l}\text { Text boxes to insert personal data } \\
\text { and button. }\end{array}$ \\
\hline
\end{tabular}

For the development of sprint 2, user stories with high priority were taken, the people responsible for each story were selected, among other aspects that will be seen in more detail in table 4 .

TABLE IV SPRINT 2 BMI CAlCUlation MenU

\begin{tabular}{|l|l|}
\hline \multicolumn{2}{|l|}{ SPRINT 2 } \\
\hline User History & $\begin{array}{l}\text { As a user, I want to register my } \\
\text { weight and height to calculate my } \\
\text { body mass index. }\end{array}$ \\
\hline Manager: & Huayllani \\
\hline $\mathrm{N}^{\circ}$ Ítem: & 3 \\
\hline Estimated Time: & 5 days \\
\hline User: & User \\
\hline Criteria of Acceptance: & $\begin{array}{l}* \text { Text boxes to insert weight and } \\
\text { height. } \\
* \text { Button that allows you to calculate. }\end{array}$ \\
\hline
\end{tabular}




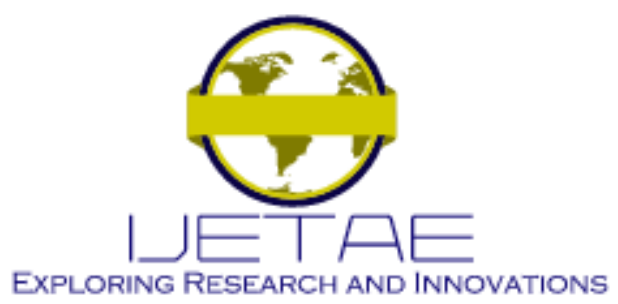

International Journal of Emerging Technology and Advanced Engineering

Website: www.ijetae.com (E-ISSN 2250-2459, Scopus Indexed, ISO 9001:2008 Certified Journal, Volume 11, Issue 12, December 2021)

For the development of sprint 3 , a user story with medium priority was taken, the people responsible for each story were selected, among other aspects that will be seen in more detail in table 5.

TABLE V

SPRint 3 ONLine CONSUltation

\begin{tabular}{|l|l|}
\hline \multicolumn{2}{|c|}{ SPRINT 3 } \\
\hline User History & $\begin{array}{l}\text { As a user, I want to be able to access } \\
\text { an online consultation to ask } \\
\text { frequently asked questions so that I } \\
\text { can have virtual support. }\end{array}$ \\
\hline Manager: & Huayllani \\
\hline $\mathrm{N}^{\circ}$ Ítem: & 4 \\
\hline Estimated Time: & 12 days \\
\hline User: & User \\
\hline Criteria of Acceptance: & $\begin{array}{l}* \text { Instant messaging box. } \\
* \text { Button that allows you to send a } \\
\text { message. }\end{array}$ \\
\hline
\end{tabular}

For the development of sprint 4 , a user story with medium priority and another one with low priority was taken, the people responsible for each story were selected, among other aspects that will be seen in more detail in table 6.

TABLE VI

SPRINT 4 My FOOD MODULE

\begin{tabular}{|l|l|}
\hline \multicolumn{2}{|c|}{ SPRINT 4 } \\
\hline User History & $\begin{array}{l}\text { As a user, I want to be able to see a } \\
\text { list of healthy foods to correct my } \\
\text { diet. }\end{array}$ \\
\hline Manager: & Huayllani \\
\hline $\mathrm{N}^{\circ}$ Ítem: & \\
\hline Estimated Time: & 3 days \\
\hline User: & User \\
\hline Criteria of Acceptance: & Healthy Food Guide Box. \\
\hline
\end{tabular}

For the development of sprint 5, a user story with low priority was taken, the people responsible for each story were selected, among other aspects that will be seen in more detail in table 7 .

TABLE VII

SPRINT 5 USER PROFILE

\begin{tabular}{|l|l|}
\hline \multicolumn{2}{|c|}{ SPRINT 5 } \\
\hline User History & $\begin{array}{l}\text { As a user, I want to access the option } \\
\text { of my profile to modify data such as } \\
\text { email, cell phone, password. }\end{array}$ \\
\hline Manager: & Huayllani \\
\hline $\mathrm{N}^{\circ}$ Ítem: & 8 \\
\hline Estimated Time: & 2 days \\
\hline User: & User \\
\hline Criteria of Acceptance: & $\begin{array}{l}* \text { Text boxes to insert email and } \\
\text { password. } \\
* \text { Button that allows you to modify. }\end{array}$ \\
\hline
\end{tabular}

\section{Sprint Review}

In Sprint 1 was made the access module, with user and password, as well as a data record as a user, email, and password that was raised in the requirements and our initial prototype was as shown in Fig 2.



Fig. 2. Login Prototype - Usage Register 




International Journal of Emerging Technology and Advanced Engineering

Website: www.ijetae.com (E-ISSN 2250-2459, Scopus Indexed, ISO 9001:2008 Certified Journal, Volume 11, Issue 12, December 2021)

In Sprint 2, the data recording module was made as weight and height to calculate its body mass index, which was raised in the requirements and our prototype was as shown in Fig. 3.



Fig. 3. Prototype BMI Calculation Menu

In Sprint 3 a Chatbots was made of how the user makes consultations or help instantly, which was raised in the requirements and our prototype was as shown in Fig. 4.

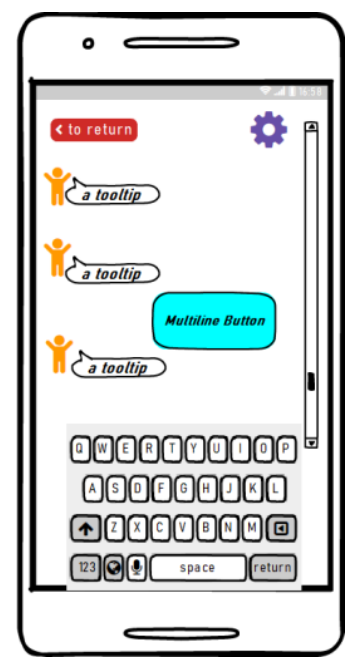

Fig. 4. Prototype Consult Online
In Sprint 4, we made a list of the healthy foods that the user should consume according to his BMI, which was raised in the requirements and our prototype was as shown in Fig. 5.

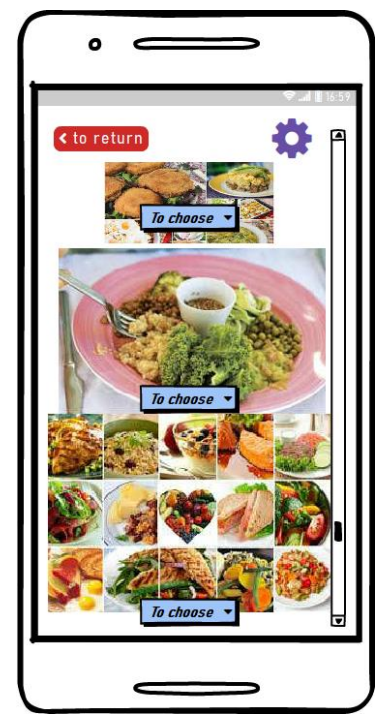

Fig. 5. My Food Prototype

In Sprint 5, a modification or update of the user's data was made, which was raised in the requirements and our prototype was as shown in Fig. 6.

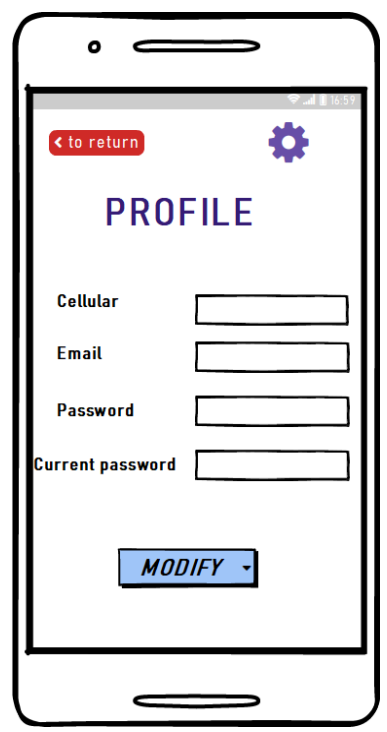

Fig. 6. Prototype My Profile 




International Journal of Emerging Technology and Advanced Engineering

Website: www.ijetae.com (E-ISSN 2250-2459, Scopus Indexed, ISO 9001:2008 Certified Journal, Volume 11, Issue 12, December 2021)

\section{RESUlTS AND Discussions}

In this section, the results achieved with the case study will be presented and the methodology will be discussed.

\section{A. About the Case Study}

As a case study, a mobile application was designed to help our users to interact easily and quickly with the functionalities that the application offers. The tool used for the design of these prototypes was Balsamiq Mockups; because of the tools it offers and its ease of use, it allows us to make good designs. In comparison with other research works, it was possible to observe the user-centered design of an Android application to locate lost animals, where their designs were made with the use of the Sketch tool, which shows that its interface is very basic and you can not make designs a little more complex as is the case of Balsamiq Mockups [17].

In another investigation that deals with a design of a mobile application to share bicycles between individuals, you can see that they used the Balsamiq Mockups tool to make their prototypes; in their designs, you can see that they are complete, all the functionalities are explained in detail [18]. It can be said that Balsamiq Mockups is one of the most complete and easy to use tools to make wireframe designs, without the need to have much knowledge since its structure is very easy to use.

According to the analysis of a national survey in Peruvian households during the years 2012 - 2013, it was possible to diagnose that overweight in Peru has a high range that exceeds at least $30 \%$ according to the age range, between 20 and 29 years there is $30.40 \%$ overweight, between 30 and 39 years there is $43.70 \%$ overweight, between 40 and 49 years there is $46.80 \%$ overweight, between 50 and 59 years there is $43.30 \%$ overweight and from 60 years on there is $38.50 \%$ overweight [19], as can be seen in Fig. 7.



Fig. 7. Percentage of overweight in Peru by age range
As can be seen in figure 7 , the percentages are high according to the age range, and we are confident that with the design of this mobile application, these percentages can be lowered in a natural way and without the need for surgical operations.

\section{B. About the Methodology}

We made with the Scrum methodology to have a work environment by stages, so meet the requirements that the user needs to use sample mobile application with a work environment during meetings for proper decision making in the sprints, and meet all stages of this methodology scrum.

Advantages: By performing dialogues in the work environment it makes the estimates more precise and detailed so that the requirements are well defined, in the same way, the user stories, to comply with the sprints in an adequate time, and then focus on the process of creating the prototype as shown in figure 4 which makes communication of consultations with chatbots for better communication which will allow not to resort to the usual, in figure 5 shows us the dishes or foods according to their BMI to consume properly; we can appreciate that the user or client will be able to make their adequate feeding with a control, having a group discussion in the methodology where you can help us to organize the activities to be done in our research work to culminate with better results [20].

Disadvantages: One disadvantage of Scrum is the difficulty for large projects which would have to be carried out in a different work environment in the same way, the price and the date of work are closed to be able to finish with the sprints for the creation of the prototype, not to comply with the activities of the estimate due to the bad execution, taking into account these disadvantages to be able to improve and to adapt in the activities organized with the methodology [20].

Comparison of Traditional Methodology - Scrum: The traditional methodology is more concerned with the detailed initial planning of projects to determine and have the scope, time and cost, to have good project management, while the Scrum framework encourages iterative decision making, whose approach is to make the deliverables that meet the requirements of customers, in table 8 you can see more detail this comparison. 


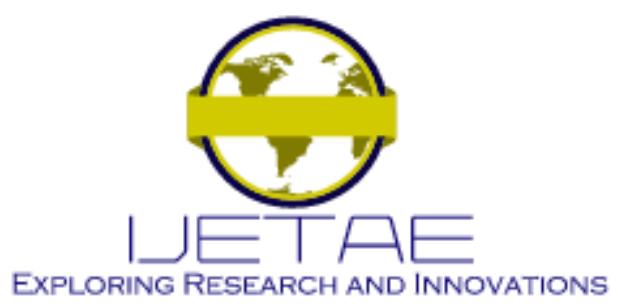

International Journal of Emerging Technology and Advanced Engineering

Website: www.ijetae.com (E-ISSN 2250-2459, Scopus Indexed, ISO 9001:2008 Certified Journal, Volume 11, Issue 12, December 2021)

TABLE VIII

COMPARISON SCRUM - TRADITIONAL METHODOLY

\begin{tabular}{|c|c|c|}
\hline Parameters & Scrum & Traditional Methodology \\
\hline Emphasis on & People & Processes \\
\hline Documentation & $\begin{array}{l}\text { Minimum - just the } \\
\text { necessary }\end{array}$ & Complete \\
\hline Style of the process & Iterative & Linear \\
\hline Initial planning & Low & High \\
\hline Prioritization of requirements & $\begin{array}{l}\text { Based on business value } \\
\text { and updated }\end{array}$ & Fixed in the Project Plan \\
\hline Quality Assurance & Customer Centric & Focus on processes \\
\hline Organization & Self-organized & Managed \\
\hline Management style & Decentralised & Centralised \\
\hline Change & $\begin{array}{l}\text { Updates to the product } \\
\text { backlog }\end{array}$ & Formal Exchange Control System \\
\hline Leadership & $\begin{array}{c}\text { Collaborative, Service } \\
\text { Leadership }\end{array}$ & Manage and control \\
\hline Measuring performance & Business Value & Plan Compliance \\
\hline Return on Investment & $\begin{array}{l}\text { Early/during the life of the } \\
\text { project }\end{array}$ & At the end of the project life cycle \\
\hline Customer Involvement & $\begin{array}{l}\text { Registration during the } \\
\text { whole project }\end{array}$ & Varies depending on life cycle \\
\hline
\end{tabular}

\section{V.CONCLUSIONS}

In this research, we managed to design a mobile application to help overweight people in Peru implemented the use of chatbots; we used the tool Balsamiq Mockups that helped design the modules of the application, thus helping to have an idea of how the application will be in its final development.
The method used was Agile and with the help of the scrum framework was able to cover all the needs of the application and thus could give value to the product also with the designs made with the tool Balsamiq Mockups complemented perfectly to carry out the final design without any hitch. 




International Journal of Emerging Technology and Advanced Engineering

Website: www.ijetae.com (E-ISSN 2250-2459, Scopus Indexed, ISO 9001:2008 Certified Journal, Volume 11, Issue 12, December 2021)

And as for future research work, we want to complement this article with the final development of the mobile application, as it can be very helpful in this society in which we live, where healthy eating goes unnoticed because there is no order at the time of choosing their food. It is hoped that this application can continue to be developed and implemented with new functionalities according to the needs of the users.

\section{REFERENCES}

[1] C. M. Kitahara, R. M. Pfeiffer, J. A. Sosa, and M. S. Shiels, "Impact of Overweight and Obesity on US Papillary Thyroid Cancer Incidence Trends (1995-2015),” J. Natl. Cancer Inst., vol. 112, no. 8, pp. 810-817, 2020, doi: 10.1093/jnci/djz202.

[2] L. Zhou et al., "Salt intake and prevalence of overweight/obesity in Japan, China, the United Kingdom, and the United States: the INTERMAP Study,” Am. J. Clin. Nutr., vol. 110, no. 1, pp. 34-40, 2019, doi: 10.1093/ajen/nqz067.

[3] R. M. P. Iparraguirre, M. M. Porras, A. H. De La Cruz, and M. L. Días Bonilla, "Prevalence of overweight and obesity in Young Peruvian students at National University of Center of Peru-Region Junin-Huancayo," Obes. Med., vol. 19, p. 100242, 2020, doi: 10.1016/j.obmed.2020.100242.

[4] S. Obrutsky and E. Erturk, "The Agile Transition in Software Development Companies: The Most Common Barriers and How to Overcome Them,” Bus. Manag. Res., vol. 6, no. 4, p. 40, 2017, doi: 10.5430/bmr.v6n4p40.

[5] M. Aguilar and C. Zapata, "Integrating UCD and an agile methodology in the development of a mobile catalog of plants," Adv. Intell. Syst. Comput., vol. 486, pp. 75-87, 2017, doi: 10.1007/978-3-319-41685-4_8.

[6] A. Srivastava, S. Bhardwaj, and S. Saraswat, "SCRUM model for agile methodology" Proceeding - IEEE Int. Conf. Comput. Commun. Autom. ICCCA 2017, vol. 2017-Janua, pp. 864-869, 2017.

[7] M. Paz-Krumdiek, S. G. Rodriguez-Vélez, P. Mayta-Tristán, and A. Bernabe-Ortiz, "Association between sitting time and obesity: A population-based study in Peru," Nutr. Diet., vol. 77, no. 2, pp. 189195, 2020, doi: 10.1111/1747-0080.12540.

[8] D. L. Kasilingam, "Understanding the attitude and intention to use smartphone chatbots for shopping," Technol. Soc., vol. 62, no. February, p. 101280, 2020, doi: 10.1016/j.techsoc.2020.101280.
[9] J. R. da Cruz, L. S. Gonçalves, and A. P. M. de A. de Giacomo, "Agile Scrum Methodology: implementation by the nurse in an educational game on safe medication management," Rev. Gauch. Enferm., vol. 40, no. spe, p. e20180302, 2019, doi: 10.1590/19831447.2019.20180302.

[10] J. Vogelzang, W. F. Admiraal, and J. H. van Driel, "Scrum methodology as an effective scaffold to promote students' learning and motivation in context-based secondary chemistry education," Eurasia J. Math. Sci. Technol. Educ., vol. 15, no. 12, 2019, doi: 10.29333/ejmste/109941.

[11] R. Coppola, L. Ardito, and M. Torchiano, "Characterizing the transition to kotlin of android apps: A study on F-Droid, Play Store, and GitHub," WAMA 2019 - Proc. 3rd ACM SIGSOFT Int. Work. App Mark. Anal. co-located with ESEC/FSE 2019, pp. 8-14, 2019, doi: $10.1145 / 3340496.3342759$

[12] M. Jumarlis and M. Mirfan, "Implementation of Markerless Augmented Reality Technology Based on Android to Introduction Lontara in Marine Society,” IOP Conf. Ser. Earth Environ. Sci., vol. 156, no. 1, 2018, doi: 10.1088/1755-1315/156/1/012017.

[13] L. Moroney and L. Moroney, "An Introduction to Firebase," Defin. Guid. to Firebase, pp. 1-24, 2017, doi: 10.1007/978-1-4842-29439_1.

[14] S. Federici et al., "Inside pandora's box: a systematic review of the assessment of the perceived quality of chatbots for people with disabilities or special needs," Disabil. Rehabil. Assist. Technol., vol. 15, no. 7, pp. 832-837, 2020, doi: 10.1080/17483107.2020.1775313.

[15] L. A. Maciaszek and J. Filipe, Evaluation of novel approaches to software engineering, vol. 410 CCIS. 2013.

[16] M. L. Sánchez Gordón, "Aproximación holística a la integración de modelos SPI en entorno microempresa," 2017.

[17] E. Serrulla García, "Diseño Centrado en el Usuario de una aplicación Android para localizar animales perdidos Trabajo Final de Grado," 2018.

[18] I. Fernández Pascual, "Diseño de la app y web de Ridehub , una aplicación para compartir bicicleta entre particulares Créditos / Copyright," 2018.

[19] J. Pajuelo Ramírez, L. Torres Aparcana, R. Agüero Zamora, and I. Bernui Leo, "El sobrepeso, la obesidad y la obesidad abdominal en la población adulta del Perú," An. la Fac. Med., vol. 80, no. 1, pp. 21-27, 2019, doi: 10.15381/anales.v80i1.15863.

[20] G. Hernández, Á. Martínez, R. Jiménez, and F. Jiménez, "Scrum and peopleware: Key elements for software development management [Scrum y Peopleware: Elementos clave para la gestión en la construcción de software],” RISTI - Rev. Iber. Sist. e Tecnol. Inf., vol. 2019, no. 19, pp. 265-277, 2019. 